\title{
KEANEKARAGAMAN DAN KELIMPAHAN JENIS LIANA (TUMBUHAN MEMANJAT) PADA HUTAN ALAM DI HUTAN PENDIDIKAN UNIVERSITAS HASANUDDIN
}

\author{
The Diversity and Abudance of Liana (Climbing Plants) in the Natural Forest of Hasanuddin University \\ Experimental Forest
}

Asrianny, Marian dan Ngakan Putu Oka

\begin{abstract}
Liana is group of climbing species which is typical and characterize the tropical rain forest. This species have important value both ecologically and economically. However, data on this group on species in South Sulawesi, in particular in the Hasanuddin University Experimental Forest is not yet available.This study aimed to determine the diversity and abudance liana species present in the natural forest area of Hasanuddin University Experimental Forest. 15 plots was set in the order to observe the diversity and abudance of liana species. The data were analysed and presented interm of important value index, diversity index, abudance index, and evenness index. The results showed that there were various species of liana in which there were found 81 species, consist of 764 individuals. The most common species was Smilax sp, wich mostly claimb on Toona sureni, Buchanania arboreschense and Flacortia rucam as a host.
\end{abstract}

Key words: diversity, abudance, liana, natural forest, Hasanuddin University Experimental Forest

\section{PENDAHULUAN}

Tumbuhan memanjat atau lebih dikenal dengan nama liana adalah salah satu jenis tumbuhan yang menjadi penciri khas dari ekosistem hutan hujan tropis. Contohnya adalah jenis-jenis rotan, anggur, serta beberapa Cucurbitaceae (suku labu-labuan). Liana merupakan tumbuhan merambat atau tidak dapat tumbuh tegak mendukung tajuknya. Untuk mendukung pertumbuhannya, kelompok tumbuhan ini umumnya memanfaatkan berbagai jenis pohon untuk merambat. Dengan memanfaatkan pohon inangnya, beberapa jenis liana dapat mencapai lapisan tajuk dan menutupi tajuk inangnya.

Secara ekologi beberapa jenis liana menjadi inang dari beberapa tumbuhan parasit yang langka contohnya bunga rafflesia. Liana memiliki peranan mencegah tumbangnya pohon akibat angin kencang, karena pertumbuhannya yang menjalar secara horizontal di antara pohon-pohon dalam hutan, namun dari segi negatifnya, tumbuhan ini dapat menyebabkan kerusakan mekanik pada pohon yang dipanjatnya. Secara ekonomi, kelompok tumbuhan ini dapat bermanfaat sebagai obat-obatan contohnya akar kuning yang biasa digunakan oleh masyarakat sekitar hutan untuk menyembuhkan penyakit. Selain itu kelompok tumbuhan ini dapat dijadikan sebagai barang kerajinan yang bernilai ekonomi contohnya tas, bakul, keranjang, kursi, meja, bola takraw dan tali pengikat.

Walaupun liana memiliki fungsi ekologi dan nilai ekonomi, namun kelompok tumbuhan ini kecuali rotan masih kurang mendapat perhatian dari masyarakat Indonesia termasuk masyarakat Sulawesi Selatan. Contoh kecil dapat dilihat pada areal Hutan Pendidikan Unhas, dimana masyarakat yang hidup/menetap di sana kebanyakan memanfaatkan hasil hutan berupa kayu, buah dan nira aren, sedangkan tumbuhan liana masih kurang dimanfaatkan bahkan tidak sama sekali. Hal ini dapat disebabkan karena masih belum adanya informasi yang lengkap mengenai potensi keanekaragaman dan kelimpahan jenis-jenis liana di hutan pendidikan tersebut. Sehubungan dengan hal itu, penelitian dilaksanakan untuk melengkapi data potensi dan keanekaragaman liana di dalam Hutan Pendidikan Unhas.

Penelitian ini bertujuan untuk mengetahui keanekaragaman dan kelimpahan jenis liana yang terdapat pada hutan alam di Hutan Pendidikan Unhas. Kegunaan dari penelitian ini yaitu untuk melengkapi data keanekaragaman jenis liana di Hutan Pendidikan Unhas dan sebagai bahan informasi kepada pengunjung mengenai keanekaragaman jenis liana pada Hutan Pendidikan Unhas. 


\section{BAHAN DAN METODE}

\section{Metode Pengumpulan Data}

\section{Orientasi Lapangan}

Orientasi lapangan dilakukan sebagai langkah awal untuk menentukan posisi plot. Dalam orientasi lapangan dilakukan perencanaan untuk menentukan lokasi pengambilan data dengan menggambarkan rencana posisi plot di atas peta kawasan Hutan Pendidikan Unhas. Lokasi yang dipilih mewakili semua tipe ekosistem yang ada di hutan alam, terutama pada areal yang diperkirakan terdapat banyak jenis liana.

\section{Pengambilan Data}

Peletakan sejumlah plot dilakukan dengan teknik sampel secara purposif yaitu meletakkan plot pada bagian hutan yang dianggap paling mewakili habitat-habitat liana. Setiap plot dibuat berukuran $20 \mathrm{~m} \times 20 \mathrm{~m}$ dan masing-masing plot dibagi lagi dalam sub-sub plot berukuran $5 \mathrm{~m} \times 5 \mathrm{~m}$ untuk memudahkan pengambilan data di lapangan. Dengan demikian terdapat 16 sub plot dalam setiap plot. Peletakan sejumlah plot ini dilakukan pada 5 lokasi pada hutan alam yang secara kasat mata nampak memiliki keanekaragaman liana yang berbeda.

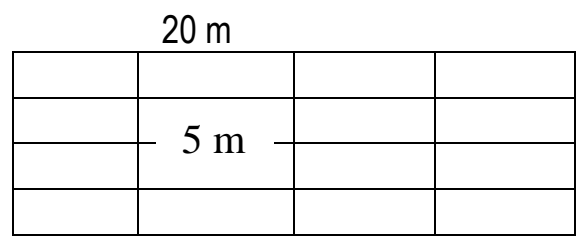

Figure 1. Observation plot of liana diversity

Parameter liana yang dicatat di lapangan adalah jenis liana, diameter liana, jenis pohon inang dan diameter pohon inang. Pengukuran dilakukan dalam setiap sub plot dengan mengidentifikasi jenis dan mengukur diameter batang setiap individu liana dan inang yang ditemukan. Pengukuran diameter liana dilakukan pada bagian batang yang berada $25 \mathrm{~cm}$ di atas sistem perakaran, sedangkan pengukuran diameter pohon inang dilakukan pada ketinggian $130 \mathrm{~cm}$ di atas permukaan tanah (30 $\mathrm{cm}$ di atas banir). Hal ini dilakukan untuk mempermudah dan menyeragamkan pengukuran di lapangan. Setiap jenis liana diambil sampel herbariumnya untuk tujuan identifikasi jenis. Beberapa karakteristik fisik setiap plot seperti posisi topografi, kelerengan, arah lereng dicatat sebagai data pelengkap untuk pembahasan. Selain karakteristik fisik dicatat berbagai karakteristik berbagai plot seperti jenis pohon dominan, tingkat penutupan tajuk dan lainnya yang ditemukan di lapangan dicatat.

\section{Pengolahan Data}

\section{Indeks Nilai Penting}

Data-data yang dikumpulkan kemudian di hitung Indeks Nilai Penting (INP). Besaran-besaran ini dihitung dengan rumus:

1. Kerapatan $(\mathrm{K})$

$=$ Jumlah individu Luas plot contoh

2. Kerapatan Relatif (KR)

$=\frac{\text { Kerapatan suatu jenis }}{\text { Kerapatan seluruh jenis }} \times 100 \%$

3. Frekuensi $(F)$

$=$ Jumlah plot ditemukan suatu jenis Jumlah seluruh plot

atau

Frekuensi ( $F)$

$=\underline{\text { Jumlah sub plot ditemukan suatu jenis }}$ Jumlah seluruh sub plot

4. Frekuensi Relatif (FR)

$=$ Frekuensi suatu jenis $\times 100 \%$

Frekuensi seluruh jenis

5. Dominansi (D)

$=\underline{\text { Jumlah luas bidang dasar suatu jenis }}$ Luas plot contoh

6. Dominansi Relatif (DR)

$=$ Dominansi suatu jenis $\times 100 \%$

Dominansi seluruh jenis

7. Indeks Nilai Penting $(\mathrm{INP})=\mathrm{KR}+\mathrm{FR}+\mathrm{DR}$

8. Luas bidang dasar $=1 / 4 \pi d^{2}$

\section{Keanekaragaman Jenis}

Tingkat keanekaragaman jenis dapat dihitung dengan menggunakan rumus sebagai berikut :

1. Indeks Keanekaragaman dengan menggunakan rumus Shannon dan Wiener:

$$
H=-\Sigma\{(n i / n) \ln (n i / n)\}
$$

di mana:

$\mathrm{H}=$ Indeks Keanekaragaman

$\mathrm{ni}=$ jumlah individu

$\mathrm{n}=$ jumlah total individu

dengan kriteria:

$\mathrm{H}^{\prime}<1=$ Menunjukkan tingkat keanekaragaman jenis yang rendah 
$1>H^{\prime}>3=$ Menunjukkan tingkat keanekaragaman jenis yang sedang

$\mathrm{H}^{\prime}>3$ = Menunjukkan tingkat keanekaragaman jenis yang tinggi

2. Kelimpahan jenis dapat dihitung dengan menggunakan rumus sebagai berikut:

$$
\mathrm{N}=\mathrm{e}^{\mathrm{H}}
$$

di mana:

$\mathrm{N}=$ Kelimpahan jenis

$\mathrm{e}=$ Bilangan natural

$\mathrm{H}=$ Indeks keanekaragaman

3. Indeks kemerataan dapat dihitung dengan rumus:

$$
E=\ln (N) / \ln (S)
$$

di mana:

$\mathrm{E}=$ indeks kemerataan

$\mathrm{N}=$ kelimpahan jenis

$S=$ jumlah jenis

Nilai indeks $\mathrm{E}$ akan berkisar antara 0 - 1. Nilai E akan mendekati 1 bila jumlah individu setiap jenis dalam satu komunitas hampir merata.

4. Indeks Kekayaan dapat dihitung dengan menggunakan rumus Menhinich:

$$
\mathrm{R}=\mathrm{S} / \sqrt{ } \mathrm{n}
$$

di mana:

$\mathrm{R}=$ Indeks Kekayaan

$\mathrm{S}=$ Jumlah Jenis

$\mathrm{n}=$ Jumlah Total Individu

\section{HASIL DAN PEMBAHASAN}

Hasil

\section{Komposisi dan sebaran jenis liana}

Pengamatan yang dilakukan pada 15 plot pengamatan memperlihatkan adanya variasi penyebaran jenis liana dimana secara keseluruhan ditemukan 81 jenis liana dengan jumlah individu sebanyak 764 individu.

Jenis liana yang paling banyak ditemukan adalah Smilax sp. Sebanyak 30 jenis lainnya tersebar pada 2 sampai 11 plot pengamatan dengan frekuensi 13,3\% sampai 73,3\%. Selebihnya, 50 jenis liana hanya ditemukan pada salah satu plot pengamatan dengan frekuensi $6,6 \%$.

Luas Bidang Dasar (LBDS) tertinggi ditemukan pada plot 10 dengan nilai $173,69 \mathrm{~cm}^{2}$, diikuti oleh plot 5 dengan nilai $137 \mathrm{~cm}^{2}$. Sedangkan LBDS terendah ditemukan pada plot 12 dengan nilai 3,58 $\mathrm{cm}^{2}$. Kedua belas plot lainnya memiliki LBDS berkisar antara 4,01 sampai $80,40 \mathrm{~cm}^{2}$. Jenis liana yang memiliki LBDS tertinggi adalah Gnetum sp.1 yang terdapat pada plot 5 dengan nilai $83,60 \mathrm{~cm}^{2}$. Sedangkan jenis liana dengan LBDS terendah adalah Metelea sp.1 yang terdapat pada plot 1 dengan nilai $0,01 \mathrm{~cm}^{2}$.

\section{Keanekaragaman jenis liana}

Keanekaragaman jenis liana yang ada dalam kelima belas plot disajikan dalam bentuk nilai indeks kekayaan, indeks kelimpahan, indeks kemerataan dan indeks keanekaragaman. Nilainilai dari keempat indeks tersebut diperlihatkan pada Tabel 1.

Table 1. The Value of richness index, abudance index, evenness index, and diversity index of lianas

\begin{tabular}{|c|c|c|c|c|}
\hline Plot & $\mathrm{R}$ & $\mathrm{N}$ & $\mathrm{E}$ & $\mathrm{H}$ \\
\hline 1 & 1,94 & 9,30 & 0,28 & 2,23 \\
\hline 2 & 2,25 & 12,55 & 0,84 & 2,53 \\
\hline 3 & 1,92 & 9,21 & 0,86 & 2,22 \\
\hline 4 & 1,36 & 11,36 & 0,95 & 2,43 \\
\hline 5 & 2,53 & 11,20 & 0,89 & 2,42 \\
\hline 6 & 1,19 & 4,29 & 0,61 & 1,46 \\
\hline 7 & 1,77 & 12,67 & 0,91 & 2.19 \\
\hline 8 & 1,49 & 7,61 & 0,88 & 2,03 \\
\hline 9 & 1,52 & 7,08 & 0,85 & 1,96 \\
\hline 10 & 1,77 & 1,44 & 0,15 & 0,37 \\
\hline 11 & 0,01 & 3,44 & 0,51 & 1,23 \\
\hline 12 & 2,23 & 9,26 & 0,87 & 2,23 \\
\hline 13 & 1,22 & 6,66 & 0,82 & 1,90 \\
\hline 14 & 1,01 & 4,58 & 0,73 & 1,52 \\
\hline 15 & 1,75 & 5,69 & 0,70 & 1,74 \\
\hline
\end{tabular}

Hutan Pendidikan Unhas memiliki indeks keanekaragaman jenis liana yang tinggi. Soerianegara dan Indrawan (1978) menyatakan bahwa, nilai indeks keanekaragaman berkisar antara 2 - 3 dimana nilai $<2$ menunjukkan indeks keanekaragaman yang rendah, nilai yang berkisar antara 2 - 3 menunjukkan sedang dan nilai $>3$ menunjukkan keanekaragaman yang tinggi.

\section{Jenis Inang dari lima liana dominan pada seluruh plot pengamatan}

Pada bagian ini disajikan lima jenis liana dan inang yang paling umum dalam kelima belas plot pengamatan. Kelima jenis liana tersebut adalah 
L1.S1.1, Personsia sp.1. Aristolochia sp.1, Smilax sp., dan Salacia sp.1. Selengkapnya liana dominan dengan pohon inangnya dapat dilihat pada Tabel 2 , $3,4,5$ dan 6 .

Table 2. The species of liana's host no

\begin{tabular}{|c|c|c|c|}
\hline $\begin{array}{l}\text { Jenis Inang/ } \\
\text { Kode Inang }\end{array}$ & $\begin{array}{c}\mathrm{N} \\
\text { (total) }\end{array}$ & $\begin{array}{c}\mathrm{N} \\
\text { (dibeliti) }\end{array}$ & $\begin{array}{c}\text { Frekuensi } \\
(\%)\end{array}$ \\
\hline Aegle marmelos & 16 & 9 & 14.75 \\
\hline Alstonia scholaris & 3 & 2 & 3.28 \\
\hline Athrophyllum sp. & 183 & 3 & 4.92 \\
\hline $\begin{array}{l}\text { Buchanania } \\
\quad \text { arboreschense }\end{array}$ & 90 & 3 & 4.91 \\
\hline Cinnamomum sp. & 48 & 3 & 4.92 \\
\hline Ficus sp. & 14 & 2 & 1.64 \\
\hline Flacourtia rucam & 55 & 2 & 3.28 \\
\hline Garcinia dulcis & 12 & 1 & 1.64 \\
\hline no.spec.l1.S3.1 & 2 & 1 & 1.64 \\
\hline no.spec.l13.S2.2 & 3 & 1 & 3.28 \\
\hline no.spec I3.S8.1 & 1 & 1 & 1.64 \\
\hline no.spec.l4.S12.1 & 2 & 1 & 1.64 \\
\hline Lauraceae & 2 & 2 & 3.28 \\
\hline Leea indica & 36 & 6 & 9.84 \\
\hline Litsea sp. & 30 & 3 & 4.92 \\
\hline Myristica sp. & 3 & 1 & 1.64 \\
\hline Nauclea sp. & 4 & 1 & 1.64 \\
\hline Nothophoeba sp. & 2 & 1 & 1.64 \\
\hline $\begin{array}{c}\text { Pterospermum } \\
\text { celebium }\end{array}$ & 17 & 2 & 3.28 \\
\hline Pterospermum sp. & 5 & 1 & 1.64 \\
\hline Syzygium sp.2 & 3 & 2 & 3.28 \\
\hline Toona sureni & 89 & 11 & 19.67 \\
\hline Urophyllum sp & 25 & 1 & 1.64 \\
\hline $\begin{array}{l}\text { Persea } \\
\quad \text { odoratissima }\end{array}$ & 23 & 1 & 1.64 \\
\hline Jumlah & 668 & 61 & 100 \\
\hline
\end{tabular}

Pada Tabel 2 diperlihatkan jenis liana dengan nomor specimen L1.S1.1 beserta pohon inangnya. Jenis liana ini ditemukan dalam 11 plot pengamatan. Dari 11 plot pengamatan tersebut jenis liana ini berasosiasi dengan 24 jenis pohon inang. Athrophyllum sp. adalah pohon inang dengan jumlah individu terbesar, yaitu 183 individu, namun demikian frekuensi jenis liana tersebut dalam berasosiasi dengan jenis pohon tersebut sebagai inang hanya 4,92\%. Dibandingkan dengan pohon Athrophyllum sp. jumlah pohon Toona sureni yang ditemukan dalam seluruh plot pengamatan hanya 89 individu, tetapi frekuensinya berasosiasi dengan liana L1.S1.1 sebesar 19,67 \%. Frekuensi asosiasi liana L1.S1.1 dengan pohon inang lainnya bervariasi antara $1,64 \%$ sampai $14,75 \%$.
Table 3. The species of liana's host for Personsia sp.1

\begin{tabular}{|c|c|c|c|}
\hline $\begin{array}{l}\text { Jenis Inang/ } \\
\text { Kode Inang }\end{array}$ & $\begin{array}{c}\mathrm{N} \\
\text { (total) }\end{array}$ & $\begin{array}{c}\mathrm{N} \\
\text { (dibeliti) }\end{array}$ & $\begin{array}{c}\text { Frekuensi } \\
(\%)\end{array}$ \\
\hline Crotoxylon sp. & 30 & 3 & 3.23 \\
\hline Flacourtia rucam & 55 & 4 & 4.30 \\
\hline Aegle marmelos & 16 & 1 & 1.08 \\
\hline Ardisia humilis & 10 & 1 & 1.08 \\
\hline Athrophyllum sp. & 183 & 9 & 9.68 \\
\hline $\begin{array}{l}\text { Barringtonia } \\
\text { acusangulata }\end{array}$ & 4 & 1 & 1.08 \\
\hline $\begin{array}{l}\text { Buchanania } \\
\quad \text { arboreschense }\end{array}$ & 90 & 12 & 12.90 \\
\hline $\begin{array}{l}\text { Chisocheton } \\
\text { maerantus }\end{array}$ & 5 & 1 & 1.08 \\
\hline Cinnamomum sp. & 48 & 4 & 4.30 \\
\hline Clidemia hirta & 4 & 1 & 1.08 \\
\hline Dillenia sp. & 6 & 2 & 2.15 \\
\hline Euodia sp. & 24 & 3 & 3.23 \\
\hline Ficus sp.1 & 14 & 5 & 5.38 \\
\hline Garcinia sp 1 & 40 & 1 & 1.08 \\
\hline Garcinia sp 3 & 14 & 2 & 2.15 \\
\hline Grewia sp & 18 & 2 & 2.15 \\
\hline No spec.I12.S1.1 & 2 & 2 & 2.15 \\
\hline No.spec.I5.S14.1 & 19 & 1 & 1.08 \\
\hline llex sp. & 6 & 1 & 1.08 \\
\hline No.spec.L1.S1.1 & 2 & 2 & 2.15 \\
\hline Leea indica & 36 & 1 & 1.08 \\
\hline Litsea sp. & 30 & 7 & 7.53 \\
\hline Meliaceae & 3 & 1 & 1.08 \\
\hline P13.S3.5 & 1 & 1 & 1.08 \\
\hline $\begin{array}{l}\text { Persea } \\
\quad \text { odoratissima }\end{array}$ & 23 & 1 & 1.08 \\
\hline $\begin{array}{c}\text { Pterospermum } \\
\text { celebium }\end{array}$ & 17 & 1 & 1.08 \\
\hline $\begin{array}{c}\text { Ptherocarpus } \\
\text { indicus }\end{array}$ & 1 & 1 & 1.08 \\
\hline Rubiaceae 2 & 3 & 1 & 1.08 \\
\hline Rubiaceae 3 & 23 & 1 & 1.08 \\
\hline Schima wallichii & 8 & 2 & 2.15 \\
\hline Sehleichera sp. & 5 & 1 & 1.08 \\
\hline Syzygium sp 6 & 2 & 1 & 1.08 \\
\hline Tiliaceae & 1 & 1 & 1.08 \\
\hline Toona sureni & 89 & 12 & 12.90 \\
\hline Urophyllum sp. & 25 & 3 & 3.23 \\
\hline Jumlah & 857 & 93 & 100 \\
\hline
\end{tabular}

Tabel 3 memperlihatkan jenis liana Personsia sp. 1 beserta pohon inangnya. Jenis liana ini juga ditemukan pada 11 plot pengamatan dan berasosiasi dengan 35 jenis pohon inang. Athrophyllum sp., adalah jenis pohon inang yang memiliki jumlah individu terbanyak yaitu 183 individu, akan tetapi frekuensi jenis liana personsia sp.1 yang berasosiasi dengan pohon inang ini hanya sebesar $9,68 \%$. Berbeda dengan pohon Athrophyllum sp., jenis pohon inang Toona sureni 
yang hanya memiliki jumlah individu sebanyak 89 individu dan pohon inang Buchanania arboreschense dengan jumlah individu 90 lebih besar, justru memiliki frekuensi asosiasi dengan liana Personsia sp.1 yang terbesar yaitu $12,90 \%$. Frekuensi asosiasi jenis liana Personsia sp.1 dengan pohon inang lain bervariasi antara 1,08 \% sampai $12,90 \%$.

Table 4. The species of liana's host for Aristolochia sp.1

\begin{tabular}{|c|c|c|c|}
\hline $\begin{array}{l}\text { Jenis Inang/ } \\
\text { Kode Inang }\end{array}$ & $\begin{array}{c}\mathrm{N} \\
\text { (total) }\end{array}$ & $\begin{array}{l}\mathrm{N} \\
\text { (dibeliti) }\end{array}$ & $\begin{array}{c}\text { Frekuensi } \\
(\%)\end{array}$ \\
\hline Aegle marmelos & 16 & 2 & 5.13 \\
\hline $\begin{array}{l}\text { Buchanania } \\
\quad \text { arboreschense }\end{array}$ & 90 & 2 & 5.13 \\
\hline Clidemia hirta & 4 & 1 & 2.56 \\
\hline Crotoxylon sp. & 30 & 1 & 2.56 \\
\hline Flacourtia rucam & 55 & 3 & 7.69 \\
\hline Garcinia sp.3 & 11 & 1 & 2.56 \\
\hline Garcinia sp.1 & 40 & 1 & 2.56 \\
\hline Grewia sp. & 18 & 1 & 2.56 \\
\hline Deynos chinensis & 1 & 1 & 2.56 \\
\hline Euphorbiaceae & 1 & 1 & 2.56 \\
\hline No spec.I12.S1.1 & 2 & 1 & 2.56 \\
\hline Aristochia Sp.1 & 1 & 1 & 2.56 \\
\hline No.spec.I14.S1.3 & 2 & 1 & 2.56 \\
\hline No.spec.I14.S1.4 & 1 & 1 & 2.56 \\
\hline No.spec.I14.S8.1 & 1 & 1 & 2.56 \\
\hline No.spec.15.S14.1 & 19 & 4 & 10.26 \\
\hline No.spec.19.S10.1 & 1 & 1 & 2.56 \\
\hline L14.S4.1 & 1 & 1 & 2.56 \\
\hline Leea indica & 36 & 4 & 10.26 \\
\hline Liliaceae & 1 & 1 & 2.56 \\
\hline $\begin{array}{l}\text { Pterospermum } \\
\text { celebium }\end{array}$ & 1 & 1 & 2.56 \\
\hline Rubiaceae & 1 & 1 & 2.56 \\
\hline Sehleichera sp. & 5 & 1 & 2.56 \\
\hline Toona sureni & 89 & 6 & 15.38 \\
\hline Jumlah & 427 & 39 & 100 \\
\hline
\end{tabular}

Jenis liana Aristolochia sp.1 beserta inangnya diperlihatkan pada Tabel 4. Jenis liana ini berasosiasi dengan 24 jenis pohon inang dan ditemukan pada 10 plot pengamatan. Jenis pohon inang Buchanania arborenchense dan Toona sureni memiliki jumlah individu yang hampir sama yaitu berturut-turut 90 individu dan 89 individu. Namun demikian frekuensi asosiasi dari jenis liana Aristolochia sp.1 terhadap inang tersebut sangat berbeda yaitu $5,13 \%$ dengan Buchanania
Table 5. The species of liana's host for Smilax sp.

\begin{tabular}{|c|c|c|c|}
\hline $\begin{array}{l}\text { Jenis Inang/ } \\
\text { Kode Inang }\end{array}$ & $\underset{\text { (total) }}{\mathrm{N}}$ & $\begin{array}{c}\mathrm{N} \\
\text { (dibeliti) }\end{array}$ & $\begin{array}{c}\text { Frekuensi } \\
(\%)\end{array}$ \\
\hline Aegle marmelos & 16 & 5 & 4.27 \\
\hline Ardisia humilis & 10 & 1 & 0.85 \\
\hline Athrophyllum sp. & 183 & 9 & 7.69 \\
\hline $\begin{array}{l}\text { Buchanania } \\
\quad \text { arboreschense }\end{array}$ & 90 & 5 & 4.27 \\
\hline Cinnamomum sp. & 48 & 4 & 3.42 \\
\hline Clidemia hirta & 4 & 1 & 0.85 \\
\hline Cratoxylon sp. & 30 & 1 & 0.85 \\
\hline Flacourtia rucam & 55 & 4 & 3.42 \\
\hline Euodia sp. & 30 & 1 & 0.85 \\
\hline Garcinia dulcis & 12 & 4 & 3.42 \\
\hline Garcinia sp 1 & 40 & 1 & 0.85 \\
\hline Garcinia sp 3 & 11 & 4 & 3.42 \\
\hline No.spec.I=L2.S2.2 & 1 & 1 & 0.85 \\
\hline No.specl14.S1.1 & 2 & 2 & 1.71 \\
\hline No.spec.I14.S1.3 & 1 & 1 & 0.85 \\
\hline No.spec.|14.S1.4 & 1 & 1 & 0.85 \\
\hline No.spec.I14.S2.1 & 1 & 1 & 0.85 \\
\hline No.spec.|14.S4.2 & 1 & 1 & 0.85 \\
\hline No.spec.|14.S5.1 & 4 & 1 & 0.85 \\
\hline No.spec.I14.S8.2 & 1 & 1 & 0.85 \\
\hline No.spec.I14.S9.1 & 1 & 1 & 0.85 \\
\hline No.specl3.S4.1 & 1 & 1 & 0.85 \\
\hline No.spec.I5.S14.1 & 2 & 1 & 0.85 \\
\hline No.spec.16.S11.2 & 1 & 1 & 0.85 \\
\hline Ilex sp. & 6 & 1 & 0.85 \\
\hline No.specL14.S4.1 & 1 & 1 & 0.85 \\
\hline No.specL14.S4.2 & 1 & 2 & 1.71 \\
\hline Lagerstroemia sp & 3 & 1 & 0.85 \\
\hline Leea indica & 36 & 13 & 11.11 \\
\hline Litsea sp. & 30 & 3 & 2.56 \\
\hline Myristica sp. & 3 & 1 & 0.85 \\
\hline Nauclea sp.1 & 4 & 1 & 0.85 \\
\hline Nauclea sp.2 & 2 & 1 & 0.85 \\
\hline Oleaceae & 2 & 1 & 0.85 \\
\hline $\begin{array}{l}\text { Pterospermum } \\
\text { celebium }\end{array}$ & 1 & 2 & 1.71 \\
\hline Rubiaceae & 1 & 1 & 0.85 \\
\hline Schima wallichii & 8 & 1 & 0.85 \\
\hline Sehleichera sp. & 5 & 5 & 4.27 \\
\hline Strychnos sp. 1 & 1 & 1 & 0.85 \\
\hline Syzygium sp.3 & 2 & 1 & 0.85 \\
\hline Toona sureni & 89 & 26 & 22.22 \\
\hline Urophyllum sp. & 25 & 2 & 1.71 \\
\hline Jumlah & 766 & 117 & 100 \\
\hline
\end{tabular}

arborenchense dan 15,38\% dengan Toona sureni. Jenis pohon inang lainnya yang juga memiliki frekuensi asosiasi yang agak besar adalah no.specimen I5.S14.1 dan Leea indica dengan nilai 10,26 \%. Asosiasi jenis liana Aristochia sp.1 
dengan pohon inang lainnya bervariasi antara $2,56 \%$ sampai $10,26 \%$.

Pada Tabel 5 diperlihatkan jenis liana Smilax sp. yang memiliki asosiasi jumlah jenis inang paling banyak mencapai 43 individu. Jenis inang Buchanania arborenchense dan Toona sureni memiliki jumlah individu yang hampir sama yaitu berturut-turut 90 individu dan 89 individu, namun frekuensi asosiasi keduanya terhadap liana Smilax sp.1 sangat berbeda. Frekuensi asosiasi liana tersebut dengan inang Buchanania arborenchense hanya sebesar 4,27 \% sedangkan dengan inang Toona sureni sebesar 22,22 \%. Frekuensi asosiasi jenis liana Smilax sp. dengan pohon inang lainnya bervariasi antara 0,85 \% sampai 3,42\%.

Jenis liana Salacia sp.1 beserta pohon inangnya diperlihatkan pada Tabel 6 . Berbeda dengan keempat jenis liana lainnya, jenis liana Salacia sp.1 lebih memilih inang Flacortia rucam untuk berasosiasi dibandingkan dengan Toona sureni. Hal ini dapat dilihat dari jumlah individu yang berbeda dari kedua inang tersebut. Untuk inang Flacortia rucam berjumlah 55 individu dan inang Toona sureni berjumlah 89 individu, namun keduanya memiliki frekuensi yang sama yaitu sebesar 9,26\%. Frekuensi asosiasi jenis liana Salacia sp.1. dengan pohon inang lainnya bervariasi anatara $0,93 \%$ sampai $7,41 \%$.

\section{Pembahasan}

\section{Keanekaragaman jenis liana}

Keanekaragaman jenis liana dipengaruhi oleh indeks kekayaan, kemerataan dan kelimpahan jenis. Keanekaragaman tertinggi ditemukan pada plot 2 yaitu 2,53. Hal ini disebabkan karena jenis liana yang terdapat dalam plot 2 lebih banyak ( 20 jenis) dibandingkan dengan yang ditemukan pada keempat belas plot lainnya. Keanekaragaman jenis suatu komunitas tinggi jika komunitas itu disusun oleh banyak jenis. Sebaliknya suatu komunitas dikatakan memiliki keanekaragaman jenis yang rendah jika komunitas itu disusun oleh sedikit jenis dan hanya sedikit jenis yang dominan (Indriyanto, 2006). Pada penelitian ini keanekaragaman jenis terendah ditemukan pada plot 10 yaitu 0,37.

\section{Kelimpahan liana}

Menurut Nyakpa dkk. (1988), pengaruh arah lereng terhadap tempat tumbuh berkaitan dengan intensitas cahaya matahari yang diterima oleh
Table 6. The species of liana's host for Salacia sp.1

\begin{tabular}{|c|c|c|c|}
\hline $\begin{array}{l}\text { Jenis Inang/ } \\
\text { Kode Inang }\end{array}$ & $\underset{\text { (total) }}{\mathrm{N}}$ & $\begin{array}{c}\mathrm{N} \\
\text { (dibeliti) }\end{array}$ & $\begin{array}{l}\text { Frekuensi } \\
(\%)\end{array}$ \\
\hline Sehleichera sp. & 5 & 2 & 1.85 \\
\hline Aegle marmelos & 16 & 3 & 2.78 \\
\hline Aporusa sp. & 6 & 1 & 0.93 \\
\hline Aristochia sp. & 1 & 1 & 0.93 \\
\hline Athrophyllum sp. & 183 & 5 & 4.63 \\
\hline $\begin{array}{l}\text { Buchanania } \\
\text { arboreschense }\end{array}$ & 90 & 3 & 2.78 \\
\hline Chanophyllum sp. & 4 & 4 & 3.70 \\
\hline Cinnamomum sp. & 48 & 8 & 7.41 \\
\hline Clidemia hirta & 4 & 1 & 0.93 \\
\hline Drypetes sp. & 1 & 1 & 0.93 \\
\hline Elaeocarpus sp. 2 & 5 & 5 & 4.63 \\
\hline Elaeocarpus sp. 3 & 1 & 1 & 0.93 \\
\hline Embelia sp. & 1 & 1 & 0.93 \\
\hline Cratoxylon sp. & 30 & 2 & 1.85 \\
\hline Euodia sp. & 30 & 2 & 1.85 \\
\hline Flacourtia rucam & 55 & 10 & 9.26 \\
\hline Garcinia dulcis & 12 & 3 & 2.78 \\
\hline Garcinia sp. 1 & 40 & 5 & 4.63 \\
\hline Garcinia sp. 2 & 1 & 1 & 0.93 \\
\hline Garcinia sp. 3 & 11 & 1 & 0.93 \\
\hline Grewia sp. & 18 & 2 & 1.85 \\
\hline No spec.l=L 6.S14.1 & 1 & 1 & 0.93 \\
\hline No.spec./12.S1.2 & 1 & 1 & 0.93 \\
\hline No.spec.L1.S1.1 & 2 & 1 & 0.93 \\
\hline No.spec,I6.S1.1 & 1 & 3 & 2.78 \\
\hline Leea indica & 36 & 7 & 6.48 \\
\hline Litsea sp. & 30 & 2 & 1.85 \\
\hline Nauclea sp 1 & 4 & 2 & 1.85 \\
\hline Parastemon sp & 2 & 2 & 1.85 \\
\hline $\begin{array}{l}\text { Persea } \\
\quad \text { odoratissima }\end{array}$ & 23 & 2 & 1.85 \\
\hline Popowia sp. & 1 & 1 & 0.93 \\
\hline Rubiaceae & 1 & 1 & 0.93 \\
\hline Santiria leavigata & 1 & 1 & 0.93 \\
\hline Schima wallichii & 8 & 6 & 5.56 \\
\hline Syzygium sp. & 1 & 1 & 0.93 \\
\hline Talauma sp. & 1 & 1 & 0.93 \\
\hline Terenna sp. & 1 & 1 & 0.93 \\
\hline Toona sureni & 89 & 10 & 9.26 \\
\hline Urophyllum sp. & 25 & 3 & 2.78 \\
\hline Jumlah & 790 & 108 & 100 \\
\hline
\end{tabular}

tumbuhan. Pada belahan bumi yang berada di Selatan Katulistiwa, lereng yang menghadap Utara dan Timur cenderung memberikan kualitas tempat tumbuh yang lebih baik dibanding lereng yang menghadap ke Selatan dan Barat. Penelitian pohon pada plot yang sama dengan penelitian liana menunjukan bahwa nilai rata-rata LBDS pohon untuk semua plot yang menghadap ke Timur dan Utara-Timur lebih besar dibandingkan dengan ratarata LBDS pohon pada plot yang menghadap Barat dan Selatan-Barat. Namun hasil penelitian ini 
menunjukkan fenomena yang berbeda atau terbalik dimana LBDS liana justru lebih besar pada plot-plot yang menghadap Barat dan Selatan-Barat. Rendahnya LBDS pada plot-plot yang berada pada lereng yang menghadap Timur dan Utara-Timur erat kaitannya dengan tingginya LBDS pohon pada plot-plot tersebut. Penutupan tajuk pohon yang lebih besar nampaknya menghambat pertumbuhan liana.

Dari 81 jenis liana yang ditemukan, liana dari famili Gnetaceae yaitu Gnetum sp.1 memiliki LBDS tertinggi. Jenis liana ini termasuk liana berkayu dengan batang yang besar dan menjalar di antara pohon inang. Anwar dkk. (1984) menyatakan bahwa, Gnetaceae merupakan liana berkayu dengan ruas yang teratur pada batangnya dan memiliki diameter yang cukup besar. Luas bidang dasar (LBDS) terkecil dimiliki oleh famili Apocynaceae dari jenis Metelea sp.1. Jenis ini menggunakan sulur untuk memanjat inangnya.

\section{Asosiasi beberapa jenis liana dengan pohon inang}

Dari semua jenis inang yang ditemukan, terdapat tiga jenis yang paling banyak ditemukan berasosiasi dengan liana yaitu Toona sureni, Buchanania arboreschense, dan Flacortia rucam. Dari ketiga jenis inang tersebut, Toona sureni paling banyak berasosiasi dengan jenis-jenis liana. Hal ini disebabkan karena jenis pohon ini memilki kulit batang yang agak kasar (Sofyan, 2005) sehingga memudahkan liana untuk melilit. Jenisjenis liana yang paling banyak memilih untuk menjadikan Toona sureni sebagai pohon inang adalah liana dengan nomor specimen L1.S1.1, Personsia sp., Aristolochia sp.1, dan Smilax sp. Jenis liana Salacia sp1. lebih memilih jenis Flacortia rucam sebagai inang. Hal ini mungkin disebabkan oleh Flacortia rucam yang berduri sehingga memudahkan jenis liana ini untuk memanjat pohon inang tersebut.
Liana Aristolochia sp.1 memiliki asosiasi ketiga tertinggi dengan Toona sureni sebagai inang. Jenis liana ini merupakan sumber pakan bagi larva beberapa jenis kupu-kupu dari genera Ornithoptera spp. dan Troides spp. (Supriyanto 1997).

\section{KESIMPULAN DAN SARAN}

\section{Kesimpulan}

Berdasarkan hasil pengamatan, analisis data dan pembahasan maka dapat ditarik kesimpulan sebagai berikut:

1. Liana yang ditemukan pada Hutan Pendidikan Unhas sebanyak 81 (delapan puluh satu) jenis, dengan jumlah individu sebanyak 764 (tujuh ratus enam puluh empat) individu.

2. Jenis liana yang memiliki penyebaran paling tinggi adalah Smilax sp.

3. Jenis inang yang paling banyak disukai oleh liana di Hutan Pendidikan Unhas adalah Toona sureni, Buchanania arboreschense dan Flacortia rucam.

\section{Saran}

Dalam penyusunan rencana pengelolaan Hutan Pendidikan Universitas Hasanuddin disarankan untuk perlu dilakukan penelitian lebih lanjut mengenai manfaat dan peran dari jenis liana tertentu yang dapat bermanfaat bagi masyarakat sekitar.

\section{DAFTAR PUSTAKA}

Anwar, J., Sangli, J., D., dan Nazaruddin H. 1984. Ekologi Ekosistem Sumatra. Gadja Mada University Press, Yogyakarta.

Table 7. The dominant host of each liana species

\begin{tabular}{cllcc}
\hline No & \multicolumn{1}{c}{ jenis Liana } & \multicolumn{1}{c}{ Jenis Inang } & $\begin{array}{c}\mathrm{N}(\text { Total) } \\
\text { Inang }\end{array}$ & $\begin{array}{c}\text { Frekuensi (\%) asosiasi dengan } \\
\text { inang }\end{array}$ \\
\hline 1 & L1.S1.1 & Toona sureni & 89 & 19,67 \\
2 & Personsia sp.1 & Toona sureni dan & 89 & 12,90 \\
& & Buchanania arboreschense & 90 & 12,90 \\
3 & Aristolochia sp.1 & Toona sureni & 89 & 15,38 \\
4 & Smilax sp. & Toona sureni & 89 & 22,22 \\
5 & Salacia sp.1 & Toona sureni dan & 89 & 9,26 \\
& & Flacortia rucam & 55 & 9,26 \\
\hline
\end{tabular}


Indriyanto. 2006. Ekologi Hutan. PT. Bumi Aksara, Jakarta.

Nyakpa, A. M. Hakim, N., M.Y. Lubis, S. G. Ngroho, M. R. Saul, M. A. Diha, G. B. Hong dan H. H Bailey. 1986. Dasar-dasar IImu Tanah. Penerbit Universitas Lampung. Bandar lampung.

Sofyan, I. 2005. Pengaruh Umur Semai Terhadap Pertumbuhan Bibit Suren Dipersemaian. (on line) http:// www. Dephut.go.id. diakses tanggal 2 Juni 2009.

Supriyanto. 1997. Explorasi jenis Kupu-kupu Sayap Burung (Ornithoptera spp.) di Kecamatan Yapen Timur Kebupaten Yapin II Yapen Waropen. Universitas Cendarawasi. Manokwari.

Diterima : 17 Oktober 2008

Asrianny, Marian dan Ngakan Putu Oka

Lab. Konservasi Sumberdaya Hutan dan Ekowisata

Fakultas Kehutanan, Universitas Hasanuddin

Kampus Tamalanrea, Jl. Perintis Kemerdekaan Km. 10, Makassar 90245

Telp./Fax. 0411-585917. Indonesia 